Jurnal Ilmu-Ilmu Peternakan 26 (3): 53 - 58

ISSN : 0852-3681

E-ISSN : 2443-0765

CFakultas Peternakan UB, http://jiip.ub.ac.id/

\title{
Pengaruh kastrasi terhadap performan produksi Sapi Persilangan Wagyu berdasarkan umur yang berbeda
}

\author{
Kuswati, Ravenska, Nareswara Hapsari, Aulia Puspita Anugra Yekti, dan Trinil Susi- \\ lawati
}

Fakultas Peternakan Universitas Brawijaya, Malang

Jl. Veteran Malang 65145 Jawa Timur

Kuswatibx@yahoo.com dan aulia_pay@yahoo.com

\begin{abstract}
The purpose of this research was to know the effect of castration to Wagyu crossbreed cattle production performance based on age difference and know the appropriate age to do castration. The materials used in this research were 37 heads of 3 month old and 28 heads 4 months calf castration. The method was case studies with purposive sampling. Data were analyzed using unpaired $t$ test. The results showed that the calf castration age of 3 months and 4 months showed significantly different $(\mathrm{P}$ $<0.05)$ in daily body weight gain and feed conversion. The average daily weight gain of 3 months old calf castration was $0.78 \mathrm{~kg} /$ head / day and 4 months old calf castration was $0.85 \mathrm{~kg} /$ head / day and feed conversion of 3 months old calf castration was 5.14 and 4 months old calf castration was 4.48 , while the feed intake of the research results were not significantly different. The average feed consumption of 3 months old calf castration was $3.82 \mathrm{~kg} /$ head / day and 4 months old calf castration was $3.66 \mathrm{~kg} /$ head / day. Calves were castrated on 4 months old showed higher daily weight gain than the calf castration on 3 months old. This could be concluded that 4 months old was more appropriate to do castration.
\end{abstract}

Keywords: Average daily gain, calf stock, feed convertion, castration

\section{PENDAHULUAN}

Wagyu merupakan sapi asli Jepang yang sudah diperkenalkan di beberapa negara. Keunggulan Wagyu dibandingkan dengan sapi lainnya adalah memiliki kualitas daging terbaik di dunia dengan rasa dan tekstur yang lembut. Wagyu terdiri dari 4 bangsa yaitu Japanese Black (Kryosh), Japanese Red (Akaushi), Japanese Shorthorn and Japanese Polled (Pezza, 2014). Japanese Black merupakan salah satu bangsa dengan banyak peminat di beberapa negara karena memiliki kualitas marbling lebih tinggi dibandingkan dengan tipe sapi Wagyu yang lain.

Industri peternakan sapi potong tidak terlepas dari manajemen dan pengelolaan yang baik dengan memperhatikan produktivitas ternak dan efisiensi pertambahan bobot badan. Kastrasi adalah manajemen rutin di sebagian besar sistem produksi ternak dengan proses menghilangkan fungsi alat reproduksi dengan cara mematikan sel kelamin jantan. Sapi kastrasi lebih mudah dalam hal penanganan dan meningkatkan kualitas daging (Grandin, 2015). Kastrasi mengakibatkan ternak 
cenderung menjadi jinak dan sifat jinak sapi adalah sifat yang diharapkan dalam usaha penggemukan karena membantu konversi pakan menjadi daging.

Kastrasi dapat dilakukan pada ternak pada usia berapapun, akan tetapi pada usia ternak yang lebih muda memberikan penyembuhan lebih cepat dan meminimalisir rasa sakit pasca kastrasi (Bretschneider, 2005). Anak sapi dengan umur lebih tua menunjukkan rasa sakit yang lebih tinggi saat dikastrasi dibandingkan anak sapi pada umur 3 minggu. Hasil penelitian Micol, et al, (2009) menyebutkan bahwa kastrasi pada umur 2 bulan memiliki pertambahan bobot badan yang lebih tinggi dibandingkan umur 10 bulan (1,63 vs 1,34 lbs/day).

Kastrasi sudah banyak dikenal dalam dunia peternakan, khususnya ternak yang ditujukan dalam penggemukan dengan tujuan mengontrol tingkat pertumbuhan ternak, efisiensi pertambahan bobot badan ternak dan memperbaiki kualitas daging (Marti S. 2014). Waktu pelaksanaan kastrasi memberikan efek terhadap kinerja selama penggemukan dan karakteristik karkas. Ternak yang dikastrasi memiliki temperamen yang lebih jinak sehingga cenderung memiliki aktifitas gerak yang sedikit. Hal itu menyebabkan lebih banyak energi yang mendukung pembentukan daging.

Berdasarkan uraian diatas maka perlu dilakukan penelitian tentang pengaruh kastrasi terhadap performan produksi sapi Persilangan Wagyu berdasarkan umur yang berbeda.

\section{MATERI DAN METODE}

\section{Lokasi dan waktu penelitian}

Penelitian ini dilaksanakan di PT. Austasia Stockfeed Unit Pembibitan Jabung Lampung Timur. Penelitian ini dilaksanakan mulai 6 September sampai 17 November 2016.

\section{Materi}

Materi yang digunakan dalam penelitian ini adalah pedet jantan sapi Persilangan Wagyu umur 3 bulan sebanyak 37 ekor dan umur 4 bulan sebanyak 28 ekor pedet.

\section{Metode}

Metode penelitian yang digunakan adalah studi kasus. Pengambilan sampel dilakukan secara purposive sampling.

\section{Prosedur penelitian}

Penimbangan saat kastrasi, perawatan 1, perawatan 2 dan penimbangan setelah sembuh dari kastrasi. Pedet jantan digiring menuju kandang penjepit kemudian dilakukan kastrasi dengan metode tertutup. Metode tertutup menggunakan cincin karet yang dimasukkan dan dikaitkan pada pangkal skrotum untuk menjepit yang dibantu dengan tang. Cincin karet dikaitkan hingga rapat, sehingga sirkulasi darah dan zat pakan yang terjadi pada bagian bawah ikatan karet terhenti. Skrotum dan testis akan mengering dan akhirnya terlepas setelah 3 minggu dikastrasi.

Penimbangan saat perawatan pedet kastrasi. Perawatan dilakukan setiap 2 minggu sekali selama 1 bulan dengan pemberian antibiotik dan antilalat pada bagian skrotum kemudian dilakukan penimbangan setelah perawatan atau saat pedet dinyatakan sembuh dari kastrasi. Pemberian pakan dilakukan 2 kali sehari dan pakan yang diberikan berupa complete feed.

Data yang diperoleh dianalisis menggunakan uji t tidak berpasangan. Variabel utama yang diamati yaitu bobot badan dan pertambahan bobot badan harian, sedangkan variabel pendukung yaitu konsumsi pakan dan konversi pakan. 
HASIL DAN PEMBAHASAN

\section{Pengaruh kastrasi terhadap pertambahan bobot badan harian}

Hasil pengamatan dari

Pertambahan Bobot Badan Harian (PBBH) pedet jantan sapi Persilangan Wagyu pada umur yang berbeda dapat dilihat pada Tabel 1. Hasil analisis data menunjukkan bahwa $\mathrm{PBBH}$ pedet yang dikastrasi pada umur 3 bulan dan 4 bulan berbeda nyata $(\mathrm{P}<0,05)$. Pedet yang dikastrasi pada umur 4 bulan memiliki pertambahaan bobot badan harian lebih tinggi dibandingkan pedet umur 3 bulan.

Tabel 1. Rata-rata dan standar deviasi pertambahan bobot badan harian pedet sapi persilangan Wagyu

\begin{tabular}{lccc}
\hline Umur & Bobot badan awal $(\mathrm{kg})$ & Bobot badan akhir $(\mathrm{kg})$ & Rata-rata PBBH \\
\hline 3 bulan & $83 \pm 12,85$ & $105 \pm 16,56$ & $0,78 \pm 0,12^{\mathrm{a}}$ \\
4 bulan & $118 \pm 32,50$ & $146 \pm 37,99$ & $0,85 \pm 0,08^{\mathrm{b}}$ \\
Rataan & $100,5 \pm 22,67$ & $125,5 \pm 27,27$ & $0,81 \pm 0,1$ \\
\hline
\end{tabular}

Keterangan: Superskrip berbeda pada kolom yang sama menunjukkan perbedaan yang nyata $(\mathrm{P}<0,05)$

Manajemen penyapihan dilakukan pada umur 3 bulan. Pedet-pedet yang berumur 4 bulan sudah melewati masa penyapihan kemudian dilakukan kastrasi. Sedangkan pedet-pedet yang berumur 3 bulan penyapihan dilakukan bersamaan dengan kastrasi, pedet umur 3 bulan memiliki tingkat stres yang lebih tinggi dan peluang cidera akibat proses pengkastrasian, karena kastrasi dilaksanakan bersamaan dengan penyapihan. Orey (2008) menyatakan bahwa stres akibat kastrasi dapat dihindari dengan melakukan prosedur kastrasi secara tepat dan menggunakan peralatan yang benar serta bersih sehingga dapat mengurangi terjadinya infeksi. Hasil penelitian yang berbeda dengan Micol et al., (2009) dalam penelitiannya yang menyatakan bahwa sapi jantan yang dikebiri pada usia 2 bulan memberikan bobot badan lebih tinggi dibandingkan dengan sapi jantan yang dikebiri pada usia 10 bulan (1,65 lbs/hari dan 1,34 lbs/hari), namun tidak sejalan dengan hasil penelitian yaitu kastrasi pada umur yang lebih muda memberikan $\mathrm{PBBH}$ yang lebih rendah.
Pedet umur 4 bulan pada perawatan kastrasi 1 mengalami penurunan bobot badan harian sebesar $0,11 \mathrm{~kg}$. Perawatan kastrasi 2 menunjukkan pertambahan bobot badan harian sebesar $0,03 \mathrm{~kg}$ dan setelah dinyatakan sembuh sebesar $0,01 \mathrm{~kg}$. Pedet umur 3 bulan menunjukkan penurunan bobot badan harian pada perawatan kastrasi 1 sebesar $0,06 \mathrm{~kg}$, sedangkan perawatan kastrasi 2 sebesar $0,02 \mathrm{~kg}$ hingga setelah sembuh mengalami penurunan bobot badan harian sebesar 0,01 kg. Dilihat pada saat periode kesembuhan kastrasi, PBBH tidak menunjukkan pertambahan bobot badan, kedua umur kastrasi menunjukkan penurunan sebesar $0,01 \mathrm{~kg}$. Hal tersebut dapat diakibatkan oleh cidera dari pelaksanaan kastrasi yang menimbulkan penurunan bobot badan harian, disamping karena konsumsi pakan dikonversi untuk proses kesembuhan kastrasi sehingga PBBH belum stabil.

Kastrasi adalah menghilangkan organ pembentuk spermatozoa. Testis memiliki dua fungsi yaitu menghasilkan spermatozoa dan hormon androgen. 
Androgen mendukung perkembangan organ aksessoris, karakteristik seksual dan perilaku ternak jantan. Androgen dapat meningkatkan perkembangan otot sejalan dengan meningkatnya retensi nitrogen. Hal tersebut juga mengingatkan bahwa dalam pertumbuhan ternak menunjukkan peningkatan ukuran linear, bobot dan retensi nitrogen. Androgen memiliki kemampuan menahan nitrogen dalam tubuh, sehingga terjadi pertambahan bobot badan karena adanya pertambahan protein. Pada ternak kastrasi mengalami pertambahan bobot badan, namun hal ini disebabkan adanya penambahan lemak akibat berkurangnya aktifitas pejantan (Ihsan, 2011). Feradis (2010) menyatakan bahwa fungsi testosteron mempengaruhi perkembangan proses fisiologis dan perkembangan ternak muda. Tanpa adanya testosteron tingkah laku seksual tidak akan timbul. Testis dihilangkan saat ternak masih muda, tidak akan berkembang sebagai ternak jantan dan terjadi kegagalan dalam perkembangan kelamin sekundernya. Sedangkan kastrasi pada ternak yang telah mencapai pubertas hanya menyebabkan sedikit perubahan pada penampilan karena sifat kelamin sekunder ataupun sifat seksual tidak menurun.

Peningkatan pertambahan bobot badan harian diimbangi dengan meningkatnya konsumsi pakan. Ratarata konsumsi pakan pedet kastrasi umur 3 bulan adalah 3,82 kg/ekor/hari sedangkan pedet kastrasi umur 4 bulan adalah 3,66 kg/ekor/hari yang secara statistik tidak berbeda nyata seperti yang disajikan pada Tabel 2.

Tabel 2. Rata-rata dan standar deviasi konsumsi dan konversi pakan pedet persilangan Wagyu

\begin{tabular}{lcc}
\hline \multicolumn{1}{c}{ Umur } & Konsumsi pakan (kg/ekor/hari) & Konversi pakan \\
\hline 3 bulan & $3,82 \pm 1,24$ & $5,15 \pm 2,70^{\mathrm{a}}$ \\
4 bulan & $3,66 \pm 1,13$ & $4,48 \pm 3,57^{\mathrm{b}}$ \\
\hline
\end{tabular}

Keterangan: Superskrip berbeda pada kolom yang sama menunjukkan perbedaan yang nyata $(\mathrm{P}<0,05)$

Pakan yang dikonsumsi pedet kastrasi baik pada umur 3 bulan dan 4 bulan ditujukan untuk penyembuhan dari kastrasi, sehingga asupan nutrisi tidak ditujukan dalam pertambahan bobot badan. Berbeda dengan penelitian yang dilakukan, pedet kastrasi baik pada umur 3 dan 4 bulan memiliki tingkat konsumsi yang relatif sama dengan pertambahan bobot badan harian yang berbeda nyata. Pedet yang dikastrasi umur 4 bulan menunjukkan pertambahan bobot badan harian yang lebih tinggi.

Pakan diberikan berupa complete feed sesuai fase yang sama yaitu fase grower dengan kandungan protein kasar $17,26 \%$, bahan kering $65 \%$ dan
ME 11.20. Konsumsi bahan kering yang dihasilkan pedet kastrasi umur 3 bulan dan 4 bulan relatif sama seperti yang tersaji pada Tabel 3.

Konsumsi BK dipengaruhi oleh beberapa hal diantaranya: 1) faktor pakan, meliputi daya cerna dan palatabilitas dan 2) faktor ternak meliputi bangsa, jenis kelamin, umur dan kondisi kesehatan ternak. Standar kebutuhan BK untuk pedet adalah 0,45-2,72 kg (NRC, 2001). Kemampuan sapi mengkonsumsi pakan dalam bentuk bahan kering setiap harinya sebanyak 3\% dari bobot badan. Konsumsi BK pedet kastrasi umur 3 bulan sebesar 2,48 kg atau sebesar $2,66 \%$ dari bobot badan, 
sedangkan pedet kastrasi umur 4 bulan sebesar $2,38 \mathrm{~kg}$ atau sebesar $1,84 \%$ dari bobot badan. Dari data tersebut diketahui bahwa konsumsi bahan kering kedua umur pedet kastrasi hampir mencukupi dari kebutuhan.

Tabel 3. Konsumsi bahan kering dan protein kasar pedet kastrasi umur 3 bulan dan 4 bulan

\begin{tabular}{lcc}
\hline \multirow{2}{*}{ Konsumsi } & \multicolumn{2}{c}{ Umur pedet kastrasi } \\
\cline { 2 - 3 } & 3 bulan & 4 bulan \\
\hline Konsumsi BK & $2,48 \mathrm{~kg}$ & $2,38 \mathrm{~kg}$ \\
Kebutuhan & $2,79 \mathrm{~kg}$ & $3,87 \mathrm{~kg}$ \\
\%BB & 2,66 & 1,84 \\
Konsumsi PK & $0,43 \mathrm{~kg}$ & $0,41 \mathrm{~kg}$ \\
Kebutuhan & $0,39 \mathrm{~kg}$ & $0,54 \mathrm{~kg}$ \\
\hline \multicolumn{1}{c}{ Konsumsi PK dari kedua umur } & lebih tinggi sebesar $0,85 \mathrm{~kg} / \mathrm{ekor} / \mathrm{hari}$ \\
kastrasi tidak menunjukkan perbedaan & dibandingkan pedet kastrasi umur 3 bu- \\
nyata. Konsumsi PK mampu memenuhi & lan sebesar 0,78 kg/ekor/hari. Oleh \\
kebutuhan ternak dari kedua umur. & karena itu kastrasi lebih tepat dilakukan \\
Konsumsi protein kasar pada ransum & pada pedet umur 4 bulan. \\
$0,100-0,598$ kg/ekor/hari untuk bobot & \multicolumn{2}{l}{}
\end{tabular}
badan $45-150 \mathrm{~kg}$ (NRC, 2001).

Tabel 2 menunjukkan bahwa rata-rata konversi pakan pedet kastrasi umur 3 bulan adalah $5,15 \pm 0,87$ sedangkan pedet kastrasi umur 4 bulan adalah $4,48 \pm 0,48$. Hasil ini secara statistik berbeda nyata, artinya perbedaan umur kastrasi pedet persilangan Wagyu memberikan perbedaan terhadap konversi pakan. Konversi pakan yang baik pada penelitian ini adalah pedet kastrasi umur 4 bulan. Angka yang lebih rendah menunjukkan efisiensi penggunaan pakan. Konversi pakan sebagai patokan untuk memantau atau menggambarkan kinerja penggemukan sapi potong. Priyanto, dkk (2015) menyatakan bahwa rendahnya angka konversi pakan menandakan ternak tersebut lebih efisien mengubah nutrisi pakan menjadi masa tubuh dengan indikasi peningkatan PBBH yang cepat dan selisih periode. yang cukup signifikan.

\section{KESIMPULAN}

Pedet kastrasi umur 4 bulan menunjukkan performan terhadap pertambahan bobot badan harian yang

\section{UCAPAN TERIMAKASIH}

Ucapan terima kasih kepada PT AusAsia Lampung yang telah memfasilitasi penelitian ini.

\section{DAFTAR PUSTAKA}

Bretschneider, G. 2005. Effects of age and method of castration on performance and stress response of beef male cattle: A review. Livestock Production Science. Volume 97, Issues 2-3, November 2005, Pages 89-100

Feradis. 2010. Reproduksi ternak. Penerbit Alfabeta. Bandung: 13-14.

Grandin, T. 2015. Improving animal welfare $2^{\text {nd }}$ Edition. Colorado State University. USA.

Ihsan, M. N. 2011. Ilmu reproduksi ternak dasar. UB Press. Malang.

Marti, S., Realini C. E., Bach, A., Pérez-Juan, M., Devant, M. 2014. Effect of castration and slaughter age on performance, carcass, and meat quality traits of Holstein calves fed a high-concentrate diet. J. Anim. Sci.2013.91:11291140. 
Micol, D., M. P. Oury, B. Picard, J. F. Hocquette, M. Briand, R. Dumont, D. Egal, R. Jailler, H. Dubroeucq, and J. Agabriel. 2009. Effect of age at castration on animal performance, muscle characteristics and meat quality traits in 26-month-old Charolais Steers. Livestock Sci. 120(12):116-126.

NRC. 2001. Nutrient requirements of beef cattle: Seventh Revised Edition: Update 2000. Subcommittee on Beef Cattle Nutrition. Committee on Animal Nutrition. National Research Council.
Orey, D. 2008. The beef cow-calf manual. Alberta Agriculture and Food. Edmonton, Alberta. Canada.

Pezza, K. 2014. Backyard farming: Raising cattle. Hatherleigh Press. New York.

Priyanto, R., A. M. Fuah dan E. L. Aditia. 2015. Peningkatan produksi dan kualitas daging sapi lokal melalui penggemukan berbasis serealia pada taraf energi yang berbeda. Jurnal Ilmu Pertanian Indonesia. 20 (2): 108114. 